\title{
Effects of Government Contracting of Services on NGOs in China: Convergence and Divergence with International Experience
}

\author{
Regina Enjuto Martinez ${ }^{2}$ Yuanyuan $\mathbf{Q u}^{1} \cdot$ Jude Howell $^{1}$ (B)
}

Accepted: 21 July 2021 / Published online: 10 September 2021

(C) The Author(s) 2021

\begin{abstract}
The government of the Communist Party of China (CPC) rolled out a national policy to contract out social and welfare services to non-governmental organizations (NGOs) in 2013. This study explores how government contracting of services affects NGOs. We examine three areas: marketization, financial dependency, and autonomy. We find significant convergence of the effects of contracting on NGOs in China with NGOs' experiences in liberal democratic countries, despite divergent political regimes. Found effects are explained by the combination of the authoritarian government of the CPC with the neoliberal governance structures introduced by contracting. Convergence with international experience despite divergent political regimes is attributed to the neoliberal essence of the policy of contracting of services.
\end{abstract}

Keywords Service contracting - Welfare - NGOs · Authoritarianism · China

Regina Enjuto Martinez

regina.enjuto_martinez@kcl.ac.uk

Yuanyuan Qu

Y.Qu7@1se.ac.uk

Jude Howell

J.a.howell@1se.ac.uk

1 Department of International Development, London School of Economics and Political Science, London, UK

2 Department of International Development, King's College London, London, UK

\section{Introduction}

In 2013, the Chinese government rolled out the national policy to contract welfare services out to non-governmental organizations (NGOs), ${ }^{1}$ the "Guiding Opinions on the Government Purchasing of Services from Social Forces" (State Council, 2013), with two main strategic aims: transform government functions, and strengthen and innovate social management ${ }^{2}$ (Central Committee of the Communist Party of China, 2014). The policy involves the separation of government and society to encourage NGOs to take up "their powers and responsibilities" and "fulfil their functions" in delivering social services that are suitable to them (CCCP, 2014: Chapter 13, Sect. 48). Contracting of services introduces the market logic into the provision of welfare services and the regulation of statesociety relations. As such, it produces stark effects on the welfare system and the operations of NGOs.

Government contracting of public services to NGOs (hereafter referred to as "contracting") has been practiced

\footnotetext{
${ }^{1}$ We use the English term NGO to refer to what in China is usually termed 'social organizations' or 'social forces'. The terms are usually composed by a variety of agencies defined by registration under the broader category of social organization (shehui zuzhi): social groups (shehui tuanti), foundations (jijinhui) and civil non-enterprise units (minban feiqiye danwei). We also include in this term non-registered grassroots and community-based groups that have an institutional setting (e.g. office, staff, governance, and activity base whether services or not), social work organizations, and government-initiated social organizations, as contracting has actually driven government departments and officials to establish their own social organizations.

2 'Social management' (shehui guanli) is a contested term in Chinese as to whether it refers to new ways in which government controls society or to genuine governmental efforts to allow for greater voice and participation. A competing term in this debate is 'social governance' (shehui zhili), which overlaps with the latter interpretation of social management (Howell, 2019).
} 
for almost four decades in Western liberal democracies as a result of neoliberal economic policy. Through the ideas of New Public Management (NPM), contracting was introduced to reduce costs (Domberger \& Jensen, 1997; Hood, 1991), improve the quality of services, transfer risks to the non-public sector, enhance government's accountability (Jensen \& Stonecash, 2005), encourage civic participation and governance (Boivard, 2007). Variation of contracting effects on cost and quality of services has been attributed to, for example, service specificity, regulatory and institutional arrangements and market characteristics (Petersen et al., 2018). However, there has been substantial evidence from liberal democracies showing similar effects of contracting on NGOs, such as economies of scale, insufficiency of funding, financial dependency, mission drift or undermining of political activism. Such similarity has been attributed to the introduction of market-based regulation to NGOs - a neoliberal marketization (Sandberg et al., 2020) or the "imposition of neoliberal governance structures" (Evans et al., 2005: 74). As neoliberal policies such as contracting travel to illiberal regimes with constrained civil societies, we would expect variation in the way contracting affects NGOs. These effects would include a less diversified market of NGO service providers, censorship, culling of political activism and increased control of NGOs that would hinder their added value. In China's case, the adoption of contracting of welfare services responds to its integration into neoliberal globalization and the extension of neoliberal reforms into the public sector (So and Chu, 2012) under the primacy of state control (Weber, 2020). Therefore, given the similarity of institutional frameworks of contracting with liberal contexts such as the USA (Jing \& Savas, 2009), we would expect variation of effects on NGOs to be caused by the different political regimes.

In this article, we investigate how government contracting of services affects NGOs in China. We find substantive convergence of Chinese NGOs with experiences of contracting in liberal democratic countries, despite divergence of political regimes. We argue that contracting puts significant pressure on NGOs, which we explore through the aspects of marketization, financial dependency, and autonomy. In contrast with previous research on contracting in China, which has implicitly or explicitly generally attributed the effects of contracting on NGOs to the authoritarian government (Chan \& Lei, 2017; Howell, 2015; Howell et al. forthcoming; Zhao et al., 2016), we argue that the nature of the political regime alone cannot fully account for the found effects. We reveal the prevalence of neoliberal structures of governance in the practice of contracting in China that operate alongside with strategies of control of the authoritarian government.

The empirical basis of this paper rests on in-depth interviews with different types of NGOs in four different locations in east, south, and north China with varying levels of contracting experience. NGOs were sampled using government lists of contracting programmes, NGO websites and personal networks with NGOs, government officials and stakeholders. NGOs were selected purposively and through snow-balling ensuring a sufficient range of organizations to minimize selection biases (Silverman, 2011). A significant array of NGOs is included to cover variability in registration status, origin, size, organizational ethos, funding source, and contracting modes and arrangements. A total of 84 organizations were interviewed between 2017 and 2019, a summary of which is provided in Table 1.

In the following, we first provide an overview of existing international literature on the impact of contracting on NGOs. Second, we examine published research on contracting in China to highlight its main findings and gaps. Third, the article examines the effects of contracting on NGOs, and offers explanations of these findings. The paper then concludes, emphasizing converge of the Chinese case with international experience of contracting, and discusses its uniqueness, if any.

\section{International Experience of Government Contracting to NGOs}

The rise of neoliberalism in the 1980s in the UK and the US fundamentally transformed the welfare and public services. Neoliberalism, as an economic policy agenda, builds on the "draw[ing] conclusions of orthodox neoclassical economics and rational choice-based theories of human behaviour" (Venugopal, 2015: 172), that "is articulated as a project to dismantle the post-war Keynesian consensus (...) and to diminish the welfare state" (ibid: 173). Neoclassical economics proposes that market-liberalizing policy enhances consumer choice and improves efficiency and service quality (Greener, 2008). These ideas materialized as New Public Management (NPM) reform of the public sector, introducing features such as downsizing and decentralization, privatization, outsourcing and contracting to the private sector and NGOs.

Since the 1990s, government funding to NGOs has been rising, leading to the period to be named "contracting era" (Gronbjerg, 1993; Salamon, 1987; Smith \& Lipsky, 1993). Contracting has seen a resurge since the post-2008 financial crisis, with austerity measures downsizing the public sector and commodifying public services. The introduction of an NPM-style contracting has notable effects on NGOs, as has been shown through evidence from liberal democratic countries. On the one hand, contracting encourages the flourishing of the third sector (Salamon, 1987) and enables the emergence and diversification of service 
Table 1 Sample of NGOs (NGOs that work across sectors have been counted in more than one category)

\begin{tabular}{|c|c|c|c|c|}
\hline & Location A & Location B & Location $\mathrm{C}$ & Location D \\
\hline \multicolumn{5}{|l|}{ Registration status } \\
\hline Registered with MoCA at respective administrative level, as: & 19 & 25 & 4 & 18 \\
\hline Social groups & 4 & 2 & 1 & 2 \\
\hline Civil non-enterprise units & 14 & 22 & 2 & 8 \\
\hline Foundations & 1 & 1 & 1 & 1 \\
\hline Registered with Industry and Commerce & 0 & 1 & 0 & 7 \\
\hline Registered with other entities (e.g., CDC) & 0 & 0 & 1 & 7 \\
\hline Not registered & 1 & 1 & 0 & 4 \\
\hline \multicolumn{5}{|l|}{ Size } \\
\hline Large (over 100 staff) & 0 & 4 & 1 & 4 \\
\hline \multicolumn{5}{|l|}{ Establishment } \\
\hline Established after 2013 & 16 & 14 & 1 & 4 \\
\hline Established by government department/official & 6 & 3 & 0 & 4 \\
\hline \multicolumn{5}{|l|}{ Funding source } \\
\hline With contracts & 19 & 21 & 3 & 23 \\
\hline Without contracts & 1 & 5 & 1 & 11 \\
\hline \multicolumn{5}{|l|}{ Service sector } \\
\hline HIV/AIDS & 2 & 9 & 2 & 14 \\
\hline Migrant workers & 4 & 4 & 1 & 9 \\
\hline Children & 7 & 10 & 0 & 8 \\
\hline People with disabilities & 4 & 1 & 0 & 4 \\
\hline Social work & 4 & 6 & 1 & 1 \\
\hline Other & 1 & 1 & 0 & 6 \\
\hline Total & 20 & 26 & 4 & 34 \\
\hline
\end{tabular}

providers (Boivard, 2007). Public funding can provide legitimacy and access to political decision-making, and continuity and predictability that ensures organizations' operations and the delivery of services (Gronbjerg, 1993). Contracting also improves NGO's services, efficiency and management practices (Nowland-Foreman, 1998); and expands NGOs' ability to deliver public goods (Kramer, 1994). On the other hand, adverse effects have been found on NGO's organizational form and practices, capacity and identity, and autonomy and independence (Edwards \& Hulme, 1995; Mcloughlin, 2011; Smith \& Lipsky, 1993). These categories of NGO activity are examined through the angles of marketization of services, financial independence, and autonomy.

Market competition does not always derive directly into partnerships between governments and NGOs; instead, it leads to favouritism of successful and trusted organizations (Casey \& Dalton, 2006). Other market distortions such as economies of scale (Boivard, 2014) and cherry-picking of clients (Buckingham, 2009) result from contracting. Market competition also increases NGOs' workloads, making organizations more bureaucratic (Cunningham \& James,
2014; Onyx et al., 2008); puts downwards pressure on employment conditions (Cunningham \& James, 2014; Evans et al., 2005); and erodes the sector's unique qualities (responsiveness to community needs, social justice and community building).

Government contracts have become the main source of NGO funding, leading to government's increased power over NGOs (Smith \& Lipsky, 1993). This drives aspects such as prioritization of upward accountability (Edwards \& Hulme, 1995; Fowler, 1997); unequal partnerships (Edwards \& Hulme, 1995); focus on service delivery and stalling advocacy activities (Casey \& Dalton, 2006). The general scarcity of funding and the market competition to obtain government contracts has reduced NGOs' effectiveness. The insecurity, insufficiency and instability of government funding (Considine, 2003; Evans et al., 2005) threatens the survival of the sector. Cost-sharing is also a significant constraint associated with public funding (Gronbjerg, 1993; Nowland-Foreman, 1998). This implies that governments free-ride on the resources gathered by NGOs and claim credit for services that are not actually funded by them (Gronbjerg, 1993). Evans and others 
(2005: 77-78, 88) argued that these effects result from the introduction of a "neoliberal governance framework" that restructures both the public sector and the relationship between government and NGOs, by inserting market-based funding structures and managerial technologies into otherwise spaces ruled by non-market dynamics (Sandberg et al., 2020). This framework is, therefore, characterized by an emphasis on managerial and business-like practices, performance measurements, and competition.

NPM-style contracts introduce a number of management contingencies (Gronbjerg, 1993) that put pressure on NGOs (Kramer, 1994) and increase NGOs' bureaucratization (Considine, 2003) and specialization. These lead NGOs to converge with private providers in terms of financial strategies and delivery styles, and to adopt behaviours required by funders - a phenomenon termed "institutional isomorphism" (DiMaggio \& Powell, 1983). In practice, this has meant diversion from core activities towards managerial and administrative tasks required by the contract (Gronbjerg, 1993; Smith \& Lipsky, 1993), which has driven the conclusion that contracting erodes NGOs' added value of community, grassroots, or volunteer-based (Considine, 2003).

Mission deflection also stems from contracting (Edwards \& Hulme, 1996; Kramer, 1994). Although, on the one hand, government funding can create new opportunities to participate in policy processes (Casey \& Dalton, 2006) and occasionally provide monetary incentives for political activism (Chaves et al., 2004); on the other hand, it can also curtail NGOs' advocacy and political activism. NGOs self-censor and minimize their political involvement because of a lack of funding for advocacy activities (Casey \& Dalton, 2006) and/or fear of losing government funding (Smith \& Lipsky, 1993). Government setting contracting agendas, objectives, and timescales leads to NGOs to focus on discreet and measurable outputs (Nowland-Foreman, 1998), diverting NGOs' political activism. This effectively leads to "silencing" of disadvantaged groups (Onyx et al., 2008), and reflects the depoliticization of social services that stems from the neoliberal logic of contracting (Evans et al., 2005).

The aforementioned findings originate from NGOs' experiences in liberal democratic countries and development organizations. There are stark commonalities in terms of the effects contracting has on NGOs' operations, financing, and autonomy. Through the forces of globalization, neoliberalism has expanded beyond Western liberal democracies and has driven regimes of all sorts to adopt NPM ideas and practices such as contracting, including authoritarian regimes in Russia (Cook et al., 2021; Skokova et al., 2018) and China (Chan \& Lei, 2017). The implementation of market-liberalizing policy is highly contextual, and the nature of the political regime is likely to play a role in shaping its specific outcomes. There is scope for future research to examine the implementation and effects of the government contracting on NGOs across different political regimes and economic systems to assess contingency, convergence and context-specific variation. In the following, we review recent research on contracting in China.

\section{Government Contracting of Services in China}

The national roll-out of contracting in 2013 in China signals the CPC's adoption of market-liberalizing policies to simultaneously reform the public sector (CCCP, 2014: Chapter 9; Guiding Opinions 2013-96) and govern statesociety relations (CCCP, 2014; State Council, 2013). These policies substantively change the logic of welfare provision, which under state socialism was based on comprehensive state provision through work units in state-owned enterprises in urban areas and rural communes; and to targeted populations with special needs (Lei \& Cai, 2018). Nowadays, contracting has commodified welfare services, reflecting the post-1990s extension of neoliberal capitalism to reform the public sector (So and Chu 2012). In its relations to NGOs, the state's adoption of market principles has introduced additional constrains to an already restrictive regulatory environment. Emerging research on contracting in China has explored a number of issues, such as the implementation of the policy, different contracting models, as well as the changes introduced to state-NGOs relations. We review this research in turn.

China's contracting policy aims to give "full play to the market mechanism" to deliver public services, selecting NGOs "in a competitive and merit-based manner" (State Council, 2013: Sect. 2.2), and organizing its methods and processes "in accordance with the factors of supply and demand (...) [and] with the principles of flexibility, openness and transparency, orderly competition, and result evaluation" (Ministry of Finance et al., 2014: Article 16). Market competition, however, has been found to be symbolic (Jing, 2012; Jing \& Chen, 2012), with local governments favouring informal contracting practices with government-organized NGOs (GONGOs) (Zhao et al., 2016) and organizations with pre-established relations (Jing, 2012; Jing \& Chen, 2012). The institutional arrangements and contracting models have been described (such as project-based, post-based contracting or the hub arrangement), and explained based on the government's incentives (Cortis et al., 2018; Ke, 2018; Lei \& Cai, 2018; Li \& Lin, 2018; Zhao et al., 2016). Incidentally, this research has also pointed out some of the effects of marketization on NGOs. 
Contracting has encouraged the development of NGOs (Jing, 2018; Jing \& Savas, 2009), expanding their capacity of social service provision (Cortis et al., 2018); increasing their legitimacy, fundraising and service capacity (Zhao et al., 2016); cultivating their professionalism and nurturing the development of the social work profession (Chan \& Lei, 2017; Cortis et al., 2018; Wen, 2017). Marketization has also added pressure on NGOs. This has usually been attributed to NGOs' lack of the professional expertise and necessary staff to deliver specialized services (Ke, 2018); but also, to the lack of managerial skills necessary for contracting (Li, 2018; Wen, 2017). Increased bureaucratization and precarious labour conditions (Cho, 2017; Cortis et al., 2018) have been associated to contracting, to the point of driving organizations out of contracted service provision work altogether ( $\mathrm{Li}, 2018)$. These effects have been attributed to shortcomings of NGOs, instead of to the contracting policy itself.

Financial uncertainty has also been linked to contracting in China. Contract funding is largely insecure, as contracts are at the whim of local officials whose priorities or preferences can easily change (Zhao et al., 2016); unstable, as they are short-term (Ke, 2018; Li, 2018); and insufficient, as for example, they do not cover the full cost of NGOs' work in the services (Ke, 2018), or NGOs are paid in arrears (Zhao et al., 2016). This uncertainty leads NGOs to accept pressures and requirements from government, such as additional work outside of the service contract (Wen, 2017), prioritizing these above the needs of service users; as well as acceptance of government intrusion into contracting activities, with contractors of small or medium size having no or little power to bargain with the government (Jing \& Savas, 2009). Therefore, Chinese NGOs have been considered "tools for implementing policy" (Mok et al., 2020: 11), or "foot soldiers" of local governments with little or no autonomy and protection (Chan \& Lei, 2017). The shortcoming of such valuable research on government contracting is that contracting effects on NGOs are neither addressed as the primary research objective (with the exception of Yu et al., 2019; Zhao et al., 2016), nor are they sufficiently explained in reference to the contracting logic common to liberal democratic contexts, that is, we argue, neoliberalism.

Contracting has been approached from the perspective state-society relations, with effects on NGOs attributed to the authoritarian nature of the Party-state (Zhao et al., 2016). For some authors, contracting has been used to eliminate organizations that do not align with the state's interests of service provision or have rights-based agendas (Cortis et al., 2018; Howell, 2015). This is branded as "local state corporatism" (Hsu \& Hasmath, 2014); "pragmatic instrumentalism" (Mok et al., 2020); or a strategy of "welfarist incorporation" (Howell, 2015). Some argue, however, that NGOs are not powerless, as through contracting, they gain access to policy-making, involve themselves in stronger administrative and media advocacy (Yu et al., 2019), or "service activism" (Yuen, 2018).

Among this emergent literature, there is scarce research that links these effects on NGOs to the neoliberal underpinnings of the contracting policy. Only some authors tangentially acknowledge the influence of neoliberal ideas or economic policies on this public sector reform in China (Jing \& Savas, 2009; Mok et al., 2020). Teets (2012) identifies China's reforms as neoliberal attempts to reduce the role of the state in the economy and welfare; and Cho (2017) emphasizes that contracting is part of China's neoliberal project. This article contributes to this emerging body of research on contracting in China, by identifying the effects of contracting on NGOs and ascertaining their origins in either the neoliberal elements of the policy and/ or the authoritarian regime. Future research can further examine the intersection between authoritarianism and neoliberalism in contracting in China, for example, with regard to the institutional setting, and add a comparative perspective from an authoritarian country to the substantive body of research on contracting in liberal democracies. In the following, we empirically identify the effects of contracting on NGOs in China.

\section{Findings}

\section{Marketization of Services}

Contracting introduces market principles into welfare services under the rationale of maximizing efficiency and reducing cost (Hood, 1991). However, marketization poses challenges to the NGO sector, related to economies of scale, insufficiency of contracting funding, and downwards pressure in employment conditions. We present evidence on these issues in China in turn.

The efficiency driver in government contracting has generally lent greater emphasis on delivering services on a scale (Boivard, 2014; Buckingham, 2009). In China, we have found preference for large organizations that can deliver "in bulk", as pointed out by an NGO in the HIV/ AIDS sector: "We have always succeeded in getting funding. If you do it on a big scale, they [the government] will support you” (Interview 82, 08.04.2019). Large organizations can usually provide services at a cheaper price and have resources that make them competitive. For example, a social work organization with over 500 staff members counted with a highly segmented staff structure with experts, and specialized administrative, research, project management, and project officer staff; as well as a planning and research department dedicated exclusively to 
bidding (Interview 41, 05.12.2018). This facilitated its success in competing for service contracts. Smaller organizations are unable to have such specialized and professionalized staff to respond to all the requirements of contracting (Interview 15, 12.06.2018). The phenomenon of economies of scale is not only related to NGOs' organizational and financial capacity to compete in the market and manage contracts, but also to deliver multiple services. Larger organizations have more resources to compete for larger contracts and deliver various services simultaneously. This indicates that the effects of marketization on NGOs are hinged upon their size, benefitting larger NGOs.

Conversely, we have also found that contract funding is generally insufficient for many NGOs to deliver services, which aggravates the issue of economies of scale. "Most project-based service contracting only provides money for services(...) A common phenomenon is "negotiation on price". The government often offers half or even less of the proposed funds, while NGOs are expected to find other sources of funding to fill the gap. This means only big NGOs can participate in service contracting" (Interview 97, 19.06.2019). Insufficiency of contracting funding adds pressure on NGOs' management of staff and employment conditions, generally meaning low salaries and increased workloads for staff, which drives to high turnover rates: "Most NGOs struggle to survive because the funding does not cover operational costs, staff and venue" (Interview 82, 08.04.2019). This leads to cost-cutting: "we have to save on staff" (Interview 105, 08.2019). This is a common problem to the NGO sector, but it appears that contracting has exacerbated it due to shortage of funding, as emphasized by the director of another NGO: "[government] funding is too limited(...) it is too little to sustain adequate salary and benefits that enable us to keep running" (Interview 110, 08.2019). This has led to cost-sharing, with organizations having to cross-subsidize contracted services (Interview 54, 08.12.2018). This pressure is felt more starkly by smaller NGOs that do not have wide funding bases from which to draw. Under the market logic to maximize efficiency, it is large organizations that have the resources to cope with these competitive pressures. This confirms that in China, as elsewhere, insufficiency of funding is central to contracting (Evans et al., 2005). However, it can also be understood as a strategy of the authoritarian government to maintain control over NGOs: "The government wants NGO services but not real big NGOs. So, limited resources also make NGOs remain small" (Interview 105, 08.2019).

Insufficiency of contracting funding can be due to market competition, or to market distortions such as prices being decided by the government. We have found instances of both these price-setting mechanisms. In some cases, NGOs submit their proposals with their service price, and the government then selects from the pool of received bids (Interview 41, 05.12.2018). Lowest price can be a decisive factor in these cases. In other cases, the price is preestablished and built into the bidding process, as emphasized by the executive director of a social work NGO: "it is the government who decides the cost" (Interview 33, 27.11.2018). The case of HIV/AIDS testing services illustrates this well, as $\mathrm{CAFNGO}^{3}$ remunerated RMB100 per person tested, independently of the difficulty and resources needed to access the person, whereas non-governmental funders had paid up to RMB250 per person tested (Interview 106, 08.2019). These issues highlight that contracting funding can put severe pressure on NGOs, especially smaller NGOs that cannot afford lower prices for their services or that do not have sufficient alternative sources of funding to cross-subsidize governmental contracted services.

We have found that marketization of services favours large scale providers and establishes a tight and insufficient contracting regime that puts pressure on smaller NGOs' organizational capacity, leading to a race to the bottom in employment conditions. We also found that NGOs are drawn into cost-sharing. Evidence from our fieldwork highlights a convergence of Chinese NGOs' experiences with that of counterparts in liberal democracies. We attribute this convergence to the neoliberal logic of contracting, which aims for maximizing economic efficiency. At the same time, however, China's divergent political regime explains the strategic and partial embracement of the free market of service provider-NGOs to remain control of NGOs' size and operations. Government's control of NGOs is evidenced through carving NGOs' financial dependency on government, as will be evidenced in the next section.

\section{Financial Dependency}

Contracts now dominate NGOs' financial landscape in China. Nevertheless, given the insufficiency, insecurity and instability of funding, they ironically also threaten the sustainability of NGOs, as will be evidenced in turn.

Government contracting in China has come hand-inhand with a drastic change in the funding landscape for NGOs, with alternative sources of funding being reduced, if not eliminated. In 2016, the government enacted the Charity Law, which allows fundraising only to certain charities that have acquired public fundraising credentials from the Ministry or Bureau of Civil Affairs at which they have registration (National People's Congress, 2016:

\footnotetext{
${ }^{3}$ China AIDS Fund for Non-Governmental Organizations, initiated by the government in 2015, sourced from annual central budget and private donations.
} 
Article 22). Additionally, the implementation of the Overseas NGO Law in 2017 has restricted Chinese NGOs' access to foreign funding and collaboration with international donors. "We have more government funding now as international funding has gone" (Interview 109, 08.2019), stated the deputy secretary of an HIV/AIDS NGO. This especially affects NGOs founded by citizens outside the government (e.g., journalists, academics, affected groups or parents) and unregistered NGOs that drew largely from this type of funding. Now, in some cases, government funding represents the majority of NGOs' yearly income. For example, a social work NGO had $86.1 \%$ of their total income in 2017 from government contracts, 8.06\% from operation and services, and 5.5\% from foundations and social donations (Interview 37, 30.11.2018). For most interviewed NGOs, the lack of alternative sources of funding and the high proportion of revenue sourced from contracting determines financial dependency on government, as emphasized by director of a foundation: "Nowadays in China, financial independence is indissociable from the fact that the majority of NGOs' funding is governmental" (Interview 27, 30.10.2018). This illustrates that contracting is the main, and increasingly the only, source of NGOs' funding.

Contracting "allows the NGO to survive" (Interview 46, 06.12.2018). Simultaneously, however, NGOs' financial dependency on contracting threatens their sustainability. First, government contracts are usually insufficient to cover operational costs and put pressure on staff, as aforementioned. Second, there is a significant uncertainty around contracting, given the fluctuation of government's service priorities and requirements to participate in contracting. The executive director of a social work NGO pointed out: "government frequently changes, for example, the Youth League this year focuses on one issue such as drugs, and the next year it focuses on another issue(...) This means that the service content is not stable(...) Projects are also not stable" (Interview 37, 30.11.2018). This is a challenge for $\mathrm{NGO}$, and it requires their adaptation to government, even in terms of target group, in order to keep the financial income flowing: "Each year the government has a program and you just need to change the project accordingly(...) The risks associated with the uncertainty of contracting are very difficult" (Interview 53, 07.12.2018). Third, funding is unstable because contracts are short-term (usually one-year) and insecure. The director of a labour NGO emphasized: "It is small money for one-year projects; extension is uncertain and if so, only for three or four months. The issue of the length and renewal of the contract is worrisome" (Interview 31, 21.11.2018). Likewise, transfer of contracting funding is frequently delayed, which puts additional pressure on NGOs: "It is sad to say, we started to work [on a contracted project] in January, and up until now, as many organizations, in August or September, we haven't received the funds" (Interview 54, 08.12.2018). This reinforces the need for NGOs to crosssubsidize or advance funds from their own resources. Overall, short-term contracts limit NGOs' sustainability, as the director of a labour NGO elaborated: "it is an issue of sustainability and it is not possible to achieve an effect" (Interview 53, 07.12.2018).

We have found evidence that highlights a salient convergence with international experience of contracting. Contracting is increasingly NGOs' main (and only) source of funding in China. Such financial dependency grants government increased power over NGOs, which responds to the authoritarian nature of the CPC's government. Additionally, government control is also exercised through the contract-related management, performance, and accountability mechanisms, which respond to the neoliberal modes of control of contracting. These will be illustrated next.

\section{Autonomy}

We have found that contracting affects NGOs autonomy because it introduces governance mechanisms that emphasise managerialism and performance measurements that lead NGOs away from their usual practices and mission. These include specifying outputs, building performance targets, monitoring and accountability requirements that increase staff workloads, and defining the service and project content. We review evidence of these issues in turn.

Contracting adds substantive workloads to NGOs as it requires administrative and monitoring tasks that lead staff to redistribute their time and effort away from the service and the needs of the target group. These management and accountability requirements can lead to NGOs' standardization: "The government manages more strictly, making our work more standardized and according to regulations, which is helpful; and it puts pressure on us to report and record our work, which we didn't do before" (Interview 31, 21.11.2018). At the same time, however, they can fundamentally change NGOs' operations and constitute a substantive challenge to NGOs' autonomy to decide how to run themselves: "[government contracts] will also affect the organizations' strategy and governance" (Interview 51, 07.12.2018). This is partly because these tasks are specialized and bureaucratic: "There is lots of paperwork involved for very small work, form after form after form(...)" (Interview 110, 08.2019). This might not be such an issue for large NGOs with a segmented labour force (Interview 41, 05.12.2018), those with sufficient resources such as GONGOs (Interview 27, 30.10.2018), or NGOs that have been purposively established to deliver contracted services, but the majority of NGOs interviewed 
indicated this had a significant impact, as another interviewee emphasized: "A lot of the NGOs' energy goes to respond to the government's expectations and requirements(...) the administrative work is very high, there is a lot of human resources put into this aspect" (Interview 37, 30.11.2018).

NGOs' autonomy is also challenged by governmentdefined project objectives, performance measurements and monitoring mechanisms. Outputs are specified by contract as government tends to define service needs and project objectives. As emphasized by the director of a labour NGO: "The government designs the project; it is not us who design the project" (Interview 31, 21.11.2018). Alternatively, NGOs design the project according to the definition or the categories of services specified by the government. This means that certain NGOs have to change their line of work: "According to these [government] requirements, we design the project. It is rare that projects address the organization's aims, for example, you cannot apply for migrant workers' projects because the government does not address this area of work" (Interview 53, 07.12.2018). This challenges NGOs' autonomy in deciding their line of work and target group. As emphasized by another NGO: "it is not possible to do weiquan [rights protection] work; it is all about services(...) But our mission is rights protection(...) There is no way to do government contract work, because the government decides what you do" (Interview 46, 06.12.2018).

Additionally, the performance evaluation mechanisms built into contracts jeopardizes NGOs' autonomy by deflecting them from their mission, as emphasized by a labour NGO: "There is the administrative work, and the great amount of reporting, and monitoring and compiling indicators (...) it is all in the direction that the government establishes" (Interview 34, 28.11.2018). To fulfil contract obligations NGOs also prioritize administrative accountability: "it [government] gives you money, so you depend on it, you cannot operate alone, you must operate according to its requirements(...) You do as the funder says." (Interview 53, 07.12.2018). Government-defined project content, objectives, and performance mechanisms compromise NGOs' autonomy to work for their constituency, define their own objectives and activities, and pursue their mission. This is a strategy through which the government steers NGOs into service delivery and deflects them from pursuing rights-based agendas and targeting certain social groups such as LGBTQ or migrant workers. These issues reflect the neoliberal logic of contracting in that it depoliticises social need, silencing NGOs' attempts to voice the needs of marginalized groups. This neoliberal function of contracting supplements the Chinese authoritarian government's aim of controlling NGOs, especially those with rights-based agendas.
For GONGOs, NGOs that have been established purposefully to deliver services, and NGOs with close connection with government officials, contracting might not pose such a challenge to their autonomy. Contracting particularly undermines the autonomy of rights-based NGOs, as the government represses their activism: "Advocacy for the delivery of services to old people is ok; that is, "Chinese advocacy"' (Interview 85, 11.04.2019). This means that engaging in contracting entails self-censorship, as indicated by an HIV/AIDS NGO with LGBTQ focus: "We have so far not been told to stop activities or negative reactions from Public Security Bureau, but that is, of course, because I apply a lot of self-censorship, we have to be careful" (Interview 115, 08.2019). For NGOs that work beyond service delivery, contracting constitutes a threat to their autonomy: "It is a big dilemma in Chinese governance, government wants services and is happy to procure, but does not want strong NGOs that operate independently(...) We want to be non-governmental, not governmental" (Interview 110, 08.2019). For such NGOs, contracting represents the "instrumentalization of NGOs, which can't pursue their mission or do their own work because of doing government work" (Interview 31, 21.11.2018).

This evidence highlights both the convergence and divergence of the Chinese case with international experience, as the government of the CPC has adopted the neoliberal principles of contracting to closely monitor NGOs or even directly determine NGO activity. This has resulted in similar effects on NGOs' autonomy as in liberal democracies; yet, its divergent authoritarian political regime explains the heightened reduction of NGOs' autonomy, and the absence of autonomous space for NGOs to pursue the organization's goals, identify and meet social need, or negotiate on behalf of the interest group or service users. NGOs also lack the space to negotiate with the government the terms and conditions of contracts and services. The government of the CPC has strategically adopted contracting because its neoliberal governance structures (e.g. funding constraints and $M \& E$ requirements) allow the crafting and controlling of a service-oriented NGO sector that can be incorporated into the welfare provision infrastructure (Howell, 2015). This undermines the growth of an autonomous civil society encompassing both needs and rights.

\section{Conclusion}

This article set out to investigate how government contracting of services affects NGOs in China. It has demonstrated pressures and constraints imposed on NGOs through the dimensions of marketization of services, 
financial dependency, and autonomy. First, the introduction of market principles has affected NGOs through economies of scale (favouring larger NGOs and trusted by the government); bureaucratization and specialization; cross-subsidization and downwards pressures in employment conditions. Second, with the shrinking of alternative sources of funding has come the rise of a contracting regime, which drives NGOs to financially depend on government. Government contracting funding, ironically, poses a threat to NGOs' sustainability given the insufficiency, instability and insecurity of funding. Third, contracting introduces strict performance, management and accountability mechanisms characteristic of the private sector that lead NGOs away from their mission, and tame rights-based and advocacy groups.

We have confirmed some of the findings of previous research on contracting of services in China (Chan \& Lei, 2017; Cho, 2017; Jing, 2015; Ke, 2018; Wen, 2017; Zhao et al., 2016). We have contributed to this research by extending the explanations provided, which have generally emphasized the CPC's authoritarianism or NGOs' shortcomings, to include the neoliberal essence of contracting policy. In all three aspects explored in this article, we have suggested that the found effects on NGOs derive from neoliberal governance mechanisms such as market pressures, financial constraints and management and performance contingencies relative to the contracting practice. Chinese NGOs' experiences of contracting converge with those of NGOs in liberal democracies, despite divergence in political regime. The neoliberal structures of governance (Evans et al., 2005) imposed by contracting explain such convergence. The peculiarity of the Chinese case is the combination of an authoritarian government and neoliberal economic policy, that is, the CPC's partial adoption of neoliberalism under the premise of state control (Weber, 2020). This can be seen in contracting by the CPC's embracing the principles of market liberalization while remaining in control of contract arrangements, prices, definition of services, and performance and accountability mechanisms. Although these traits can also be found in liberal democracies, unlike its counterparts, NGOs in China lack mechanisms to negotiate and/or dispute the state. Contracting of services in China is, therefore, used in a twofold way: first, as an economic policy to reform the welfare system in the name of efficiency and quality; second, as a mechanism to secure the government's overall control of service-oriented providers. The neoliberal governance structures of contracting operate in the CPC's interest of maintaining control of both the market and civil society. The CPC's adoption of neoliberal policies has significant connotations for our understanding of the changing ideology of the Chinese Party-state in particular, and the direction of China's development in general. These areas would prove fruitful for future analysis. From the perspective of NGOs' financial and operational strategy, convergence of such adverse effects begs the question of why to engage in contracting of services and how to develop coping strategies to retain some autonomy.

This article does not intend to question the efficiency and quality gains, or the management improvements and overall development of NGOs that contracting might have brought about. However, the former are yet to be demonstrated by empirical research; and the latter should be balanced against the challenges contracting imposes to the development of an expanded NGO sector that can play a role in society in delivering welfare services, voicing needs, and protecting and advocating rights. Our findings are based on an $\mathrm{N}=84$ sample of varied NGOs, most of which were non-government-initiated. This study is limited in its representativeness of all the population of NGOs in China, which after 2013 is increasingly becoming closer to government (Snape, 2019). We have suggested patterns of effects of contracting across different types of NGOs: for example, effects of the marketization of services and financial constraints can vary depending on the size of NGO; and there might be varied degrees of autonomy depending on registration status and origin. There is scope for research that further dissects said effects on different types of NGOs. Moreover, future research can contribute to our understanding of how contracting affects NGOs and NGO-state relations by studying geographical, service sector and institutional variation of contracting within China. This could identify alternative explanations to those provided in this article. We, however, hope that this article stimulates further studies to disentangle the characteristics of the authoritarian regime (Howell et al. forthcoming) from the neoliberal governance structures that impinge contracting. Equally, we anticipate this would spur the debate on the role of regime-type in shaping convergence and divergence of contracting experiences internationally, and in welfare provision more generally.

Acknowledgements Research for this paper has been funded by the Economic and Social Research Council (ESRC) ES/P001726/1

Open Access This article is licensed under a Creative Commons Attribution 4.0 International License, which permits use, sharing, adaptation, distribution and reproduction in any medium or format, as long as you give appropriate credit to the original author(s) and the source, provide a link to the Creative Commons licence, and indicate if changes were made. The images or other third party material in this article are included in the article's Creative Commons licence, unless indicated otherwise in a credit line to the material. If material is not included in the article's Creative Commons licence and your intended use is not permitted by statutory regulation or exceeds the permitted use, you will need to obtain permission directly from the copyright holder. To view a copy of this licence, visit http://creativecommons. org/licenses/by/4.0/. 


\section{References}

Boivard, T. (2007). Beyond engagement and participation: User and community coproduction of public services. Public Administration Review, 67(5), 846-860.

Boivard, T. (2014). Efficiency in third sector partnerships for delivering local government services: The role of economies of scale, scope and learning. Public Management Review, 16(8), 1067-1090.

Buckingham, H. (2009). Competition and contracts in the voluntary sector: Exploring the implications for homelessness service providers in Southampton. Policy and Politics, 37(2), 235-254.

Casey, J., \& Dalton, B. (2006). The best of times, the worst of times: Community-sector advocacy in the age of "compacts." Australian Journal of Political Science, 41(1), 23-38.

Central Committee of the Communist Party of China (2014). Decision of the Central Committee of the Communist Party of China on some major issues concerning comprehensively deepening the reform. Third plenary session of the 18th Central Committee of the Communist Party of China, http://www.china.org.cn/china/ third_plenary_session/2014-01/16/content_31212602.htm Accessed from 03 Mar 2020.

Chan, C. K., \& Lei, J. (2017). Contracting social services in China: The case of the integrated family services centre in Guangzhou. International Social Work, 60(6), 1343-1357.

Chaves, M., Stephens, L., \& Galaskiewicz, J. (2004). Does government funding suppress nonprofits' political activity? American Sociological Review, 69(2), 292-316.

Cho, M. Y. (2017). Unveiling neoliberal dynamics: Government purchase (goumai) of social work services in Shenzhen's urban periphery. The China Quarterly, 230, 269-288.

Considine, M. (2003). Governance and competition: The role of nonprofit organisations in the delivery of public services. Australian Journal of Political Science, 38(1), 63-77.

Cook, L.J., Iarskaia-Smirnova, E., and Tarasenko, A. (2021). Outsourcing social services to NGOs in Russia: federal policy and regional responses. Post-Soviet Affairs, 37(2), 119-136.

Cortis, N., Fang, Q., \& Dou, Z. (2018). Social service purchasing in China: Rationale, features and risks. Asian Social Work and Policy Review, 12(3), 1-9.

Cunningham, I., \& James, P. (2014). Public service outsourcing and its employment implications in an era of austerity: The case of British social care. Competition and Change, 18(1), 1-19.

DiMaggio, P. J., \& Powell, W. W. (1983). The Iron Cage revisited: Institutional isomorphism and collective rationality in organizational fields. American Sociological Review, 48(2), 147-160.

Domberger, S., \& Jensen, P. (1997). Contracting out by the public sector: Theory, evidence, prospects. Oxford Review of Economic Policy, 13(4), 67-78.

Edwards, M., \& Hulme, D. (Eds.). (1995). Beyond the magic bullet: NGO performance and accountability in the Post Cold-War World. West Hartford.

Edwards, M., \& Hulme, D. (1996). Too close for comfort? The impact of official aid on nongovernmental organizations. World Development, 24(6), 961-973.

Evans, B., Richmond, T., \& Shields, J. (2005). Structuring neoliberal governance: The non-profit sector, emerging new modes of control and the marketization of service delivery. Policy and Society, 24(1), 73-97.

Fowler, A. (1997). Striking a balance: A guide to enhancing the effectiveness of NGOs in international development. Earthscan.

Greener, I. (2008). Markets in the public sector: When do they work, and what do we do when they don't? Policy and Politics, 36(1), 93-108.

Gronbjerg, K. (1993). Understanding non-profit funding. Jossey-Bass.
Hood, C. (1991). A public management for all seasons? Public Administration, 69, 3-19.

Howell, J., Enjuto Martinez, R., \& Qu, Y. (forthcoming). The authoritarian footprint on welfare: Services contracting to NGOs in China.

Howell, J. (2015). Shall we dance? Welfarist incorporation and the politics of state-labour NGO relations. The China Quarterly, 223, 702-723.

Howell, J. (2019). NGOs and civil society: The politics of crafting a civic welfare infrastructure in the $\mathrm{Hu}-\mathrm{Wen}$ period. The China Quarterly, 237, 58-81.

Hsu, Y. J., \& Hasmath, R. (2014). The local corporatist state and NGO relations in China. Journal of Contemporary China, 23(87), 516-534.

Jensen, P., \& Stonecash, R. (2005). Incentives and the efficiency of the public sector-outsourcing contracts. Journal of Economic Surveys, 19(5), 767-787.

Jing, Y., \& Savas, E. S. (2009). Managing collaborative service delivery: Comparing China and the United States. Public Administration Review, 69, 101-107.

Jing, Y. (2012). From stewards to agents? Intergovernmental management of public-nonprofit partnerships in China. Public Performance \& Management Review, 36(2), 230-252.

Jing, Y. (2015). Between control and empowerment: Governmental strategies toward the development of the non-profit sector in China. Asian Studies Review, 39(4), 589-608.

Jing, Y. (2018). Dual identity and social organizations' participation in contracting in Shanghai. Journal of Contemporary China, 27(110), 180-192.

Jing, Y., \& Chen, B. (2012). Is competitive contracting really competitive? Exploring government-nonprofit collaboration in China. International Public Management Journal, 15(4), 405-428.

Ke, Y. (2018). Services for disabled people in Xiamen. In J. Lei \& C. K. Chan (Eds.), China's Social Welfare Revolution: Contracting out social services (pp. 135-147). Routledge.

Kramer, R. (1994). Voluntary agencies and the contract culture: Dream or nightmare? Social Service Review, 68, 33-60.

Lei, J., \& Cai, T. (2018). Conclusion: Similarities and differences of contracting out social services in China. In J. Lei \& C. K. Chan (Eds.), China's Social Welfare Revolution: Contracting out social services (pp. 148-161). Routledge.

Li, X. (2018). Services for migrant workers in Jinhua. In J. Lei \& C. K. Chan (Eds.), China's Social Welfare Revolution: Contracting out social services (pp. 105-121). Routledge.

Li, X., \& Lin, J. (2018). Drug rehabilitation services in Shenzhen. In J. Lei \& C. K. Chan (Eds.), China's Social Welfare Revolution: Contracting out social services (pp. 56-71). Routledge.

Mcloughlin, C. (2011). Factors affecting state-non-governmental organisation relations in service provision: Key themes from the literature. Public Administration and Development, 31(4), $240-251$

Ministry of Finance, Ministry of Civil Affairs, and State Administration for Industry and Commerce (2014), Interim Measures for the Administration of Government Purchase of Services, Document 96, http://zhs.mof.gov.cn/zhengwuxinxi/zhengcefabu/ 201501/t20150104_1175300.html Accessed from 15 Aug 2020.

Mok, K. H., Chan, C. K., \& Wen, Z. (2020). State-NGO relationship in the context of China contracting out social services. Social Policy and Administration, 55, 687-701.

Nowland-Foreman, G. (1998). Purchase-of-service contracting, voluntary organizations, and civil society. American Behavioural Scientist, 42(1), 108-123.

National People's Congress (2016). Charity Law, http://www.gov.cn/ zhengce/2016-03/19/content_5055467.htm Accessed from 15 Aug 2020. 
Onyx, J., Dalton, B., Melville, R., Casey, J., \& Banks, R. (2008). Implications of government funding of advocacy for third-sector independence and exploration of alternative advocacy funding models. Australian Journal of Social Issues, 43(4), 631-648.

Petersen, O. H., Hjelmar, U., \& Vranbaek, K. (2018). Is contracting out of public services still the great panacea? A systematic review of studies on economic and quality effects from 2000 to 2014'. Social Policy and Administration, 52(1), 130-157.

Salamon, L. M. (1987). Partners in public service: The scope and theory of government-nonprofit relations. In W. W. Powell (Ed.), The Nonprofit Sector - A Research Handbook (pp. 99-117). Yale University Press.

Sandberg, B., Elliott, E., \& Petchel, S. (2020). Investigating the marketization of the nonprofit sector: A comparative case study of two nonprofit organizations. VOLUNTAS International Journal of Voluntary and Nonprofit Organizations, 31, 494-510.

Silverman, D. (2011). Qualitative research: Issues of theory, method and practice. Sage.

Skokova, Y., Pepe, U., \& Krasnoposkaya, I. (2018). The non-profit sector in today's Russia. Between confrontation and co-optation. Europe Asia Studies, 70(4), 531-563.

Smith, S. R., \& Lipsky, M. (1993). Nonprofits for hire: The Welfare State in the age of contracting. Harvard University Press.

Snape, H. (2019). Painting in grey and permeating gaps: Changing the space for Chinese NGOs. Made in China Journal, 4(2), 35-41.

So, A. Y., \& Cho, Y. (2012). The transition from neoliberalism to state neoliberalism in China at the turn of the twenty-first century. In C. K. Sup, B. Fine, \& L. Weiss (Eds.), Developmental politics in transition: The neoliberal era and beyond (pp. 166-187). Palgrave Macmillan.
State Council (2013). Guiding opinions on government purchasing of services from social organizations, Document 96, http://www. gov.cn/zwgk/2013-09/30/content_2498186.htm Accessed from 03 Mar 2020.

Teets, J. (2012). Reforming service delivery in China: The emergence of a social innovation model. Journal of Chinese Political Science, 17, 15-32.

Venugopal, R. (2015). Neoliberalism as concept. Economy and Society, 44(2), 165-187.

Weber, I. (2020). Origins of China's contested relation with Neoliberalism: Economics, the World Bank, and Milton Friedman at the dawn of reform. Global Perspectives, 1(1), 1-14.

Wen, Z. (2017). Government purchase of services in China: Similar intentions, different policy designs. Public Administration and Development, 37, 65-78.

Yu, J., Shen, Y., \& Li, Y. (2019). Understanding the effect of central government funding on the service and advocacy roles of nonprofit organizations in China: A cross-regional comparison. Nonprofit and Voluntary Sector Quarterly, 50, 186-212.

Yuen, S. (2018). Negotiating service activism in China: The impact of NGOs' institutional embeddedness in the local state. The Journal of Contemporary China, 27(111), 406-422.

Zhao, R., Wu, Z., \& Tao, C. (2016). Understanding service contracting and its impact on NGO development in China. VOLUNTAS International Journal of Voluntary and Nonprofit Organizations, 27, 2229-2251.

Publisher's Note Springer Nature remains neutral with regard to jurisdictional claims in published maps and institutional affiliations. 